\title{
Cerebral Neoplasm
}

National Cancer Institute

\section{Source}

National Cancer Institute. Cerebral Neoplasm. NCI Thesaurus. Code C4874.

A primary or metastatic neoplasm that affects the cerebral hemispheres. 